\title{
Economic Mechanism for Managing the Strategic Development of Territorial Communities
}

\author{
I.H. Tkachuk ${ }^{1}$, Yu.M. Melnychuk ${ }^{2}$, D.Yu. Tkachuk ${ }^{1}$, \\ I.M. Kyryliuk ${ }^{2}$, T.V. Solodzhuk ${ }^{1}$ \\ ${ }^{1}$ Vasyl Stefanyk Precarpathian National University, Shevchenko str., 57, Ivano-Frankivsk, Ukraine \\ ${ }^{2}$ Pavlo Tychyna Uman State Pedagogical University, Sadova str, 2, Uman, Ukraine
}

\begin{abstract}
The article "Economic Mechanism for Managing Strategic Development of Territorial Communities" focuses on the problems of forming a mechanism for managing strategic development of territorial communities. The purpose of the article is to determine the basics of the financial and economic mechanism regarding self-government and selffinancing of united territorial communities. The subject of research is the process of forming an economic mechanism for managing a territorial community, as a set of economic, legal levers and financial instruments, relationships and institutions that ensure the effective involvement of all resources (natural, human, transport, social structure, etc.) in the economic circulation in the system of a single economic complex of Ukraine.
\end{abstract}

Keywords - management, economic mechanism, territorial communities, strategic development.

\section{Introduction}

Territorial communities serve as the basic link in the system of governance in Ukraine, where power is reoriented to the territorial level; the influence of central government on the formation of territorial development strategies is weakened, the marginal relations are not replaced by

DOI: 10.18421/TEM94-36

https://doi.org/10.18421/TEM94-36

Corresponding author: Yuliia Melnychuk,

Pavlo Tychyna Uman State Pedagogical University,

Sadova str, 2, Uman, Ukraine.

Email: melnichyk yuliya@ukr.net

Received: 10 May 2020.

Revised: 22 September 2020.

Accepted: 30 September 2020.

Published: 27 November 2020.

(c))BY-NC-ND (C) 2020 I.H. Tkachuk at al; published by UIKTEN. This work is licensed under the Creative Commons Attribution-NonCommercial-NoDerivs 4.0 License.

The article is published with Open Access at www.temjournal.com the equivalents of financial and economic ties and dependencies. Restructuring of economic relations, improvement of financial and economic capacity of self-government actualize questions of direct dependence of economic and financial opportunities on efficient management and rational use of resources available in the territory. It is in the conditions of self-government that territorial communities acquire the ability to independently, without agreement with the departmental management bodies, influence the formation of a strategy for the development of production of the territory.

Science-based system of priorities, financial and economic mechanism, protectionism, economic stimulation of the location of production will contribute to the proportional and effective functioning of the regional system. An important condition for ensuring self-organization of territorial development in Ukraine is the creation of its own economic basis of territorial entities caused by two circumstances. First, the fulfillment of the rights and functions of local self-government bodies by real economic and political power is possible only in the presence of their own economy, which they own, use and dispose of (natural, financial resources, human capital).

Second, the continuation of the process of socialization of production at the territorial level, the organizational ordering of the whole process on the basis of technological integrity in order to strengthen economic ties between territories.

The formation of the economic mechanism and economic ties between the territories has been formed for centuries and has acquired a modern look [1].

The Law on Property enshrines the organizational and political conditions for the effective functioning of territorial entities, where each of them is economically equal. However, territorial formation the community acts as a complete system of a single economic complex with interrelated features: the nature of industrial specialization, and the degree of 
complexity of its development. Newly formed united communities act as territorial property entities and have the right to attribute work results.

The creation of a territorial community is an urgent issue today due to the progress of administrative reform in Ukraine, which necessitates investment attractiveness as a key means of mobilizing internal and external resources for socioeconomic expansion of territories [2].

The territorial ownership of the concept is cumulative. It covers state-owned, private, municipal and other property. In this case, the property, in its direct form, gives the right to appropriate the results of work and as a function to ensure profit.

The coverage of state, private municipal and other property by the territorial community is historically formed and is explained by the improvement of economic relations in society, which is important in the formation of relations in the community [3].

Property, as a function, is managed by selfgovernment bodies, and property as a condition of appropriation is its primary subjects: the state, cooperatives, individuals. In this form, it is difficult to imagine territorial ownership, to carry out spatial planning, thus providing extended reproduction.

In this context, it is advisable to establish the size of local property, based on the level of socialization achieved in the region and the necessary sufficiency in ensuring the economic conditions of self-financing and self-sufficiency [4]. The main criterion should be the level of real socialization by means of production of the region, adjusted to the needs of reasonable sufficiency of such a type of production, which would allow the region to switch consumption of products of its own production to the maximum, and the right to enter into interregional ties.

The starting point in this process should be to orient the activities of the territorial community based on technological, economic, organizational prerequisites. Since inefficiency arises where technological integrity is lost, economic ties between territories are weakened; cooperation in the priority is given to foreign partners at the expense of developing ties between regions. Under such conditions, it is possible to speak about the equal rights of regions to state property. This is an important factor in establishing close inter-territorial links, capital overflow, moving goods, workers, and more. State-owned enterprises are integrated into the system of regional economy through participation in solving socio-economic problems of the region and the community. For example, social infrastructure, small and medium-sized enterprises are fully subordinated to local governments. These enterprises feel the greatest need to develop intra-regional economic ties and to solve regional tasks.
It allows us to outline territorial property, which is the object of land, natural resources, material production enterprise, organization of work within social and spiritual institutions located in the respective territory and enshrined in the Law of Ukraine on property, creates material conditions and strengthens the power of self-government bodies, their ability to provide resources as owners of the territory and responsibility for it.

The economic basis of self-government bodies will be their role in fulfilling their constitutional responsibilities.

Another important slice of property is the material basis of self-government. It is a powerful source for creating economic incentives and interests for locals. For example, a territorial community has a certain property, the realization of which directly affects the living standards of citizens, and then they will be interested in maintaining and multiplying this property. This will generate regional economic interest, as an indispensable condition for the development of the territory creates the necessary conditions for independent development of the territory, management of the economy on the basis of program planning, investment policy, regional tax systems, pricing, remuneration, permanent sources of financial, economic, material and technical resources, and its own currency resources, the use of foreign economic potential for the creation and development of socio-economic environment.

\section{Analysis of Recent Research and Publications on the Problem}

The issue of economic development and functioning of the socio-economic environment of territorial entities, the elimination of contradictions between the subjects of the reproduction process is devoted to the monograph I.H. Tkachuk [1]. However, the publication has not yet found in the publication a holistic vision of the independent development of territorial communities, the economic mechanism of self-government and forms of self-financing.

The issues of territorial communities have received a great deal of attention in the field of economic science, but little attention has been paid to the issues of strategic development, especially the management of strategic development of territorial communities.

An indispensable condition for the development of territories is the state of the regional system in which self-government bodies develop and implement a strategy and tactics for solving a set of problematic problems in the sphere of investment, program management and financing, production organizations, availability of permanent sources of 
financial, material and technical resources, rules for the functioning of regional financial credit system, tax system, pricing and more [5]. In a market economy, all business entities (both sectoral and territorial) should have full financial freedom. Only in conditions of free economic relations, economic entities achieve their highest efficiency, especially when it comes to territorial communities. It should be considered first of all as an economic space for the activity of enterprises within a certain territory on the principles of financial efficiency, financial expediency, as a relatively independent social and financial system of reproduction [6].

Self-financing of the simple and extended reproduction at the expense of the earned money to the territorial community should have sufficient rights and resources [7]. This is the objective criterion for the distinction between the appropriation of funds and the results of production between an enterprise of the economy and the state.

In order to clearly define the boundaries of economic autonomy of the united territorial communities, and their economic autonomy, it is important to define principles that would set a reasonable boundary in using economic opportunities aimed at socio-economic development to eliminate conflicts between territorial actors of the reproduction process [8], [9].

The magnitude, complexity and controversy of the mechanisms that determine the state of financial management, determine the need for the formation of scientific and legal bases for its provision. This, in turn, increases the relevance of the tasks related to the organization of the activities of entities providing the financial management. This is especially true of the prerequisites for the transition to financial autonomy of the industry, namely the creation of an independent environment for the activity of any industry [10].

As the relations between the entities operating in the territory of local self-government and external relations are generalized, the assessment of the level of self-financing is formed by the economic model of the territorial community. This model should be built on a legislative basis by a single methodology, worked out principles of economic relations between territorial communities and state bodies, other communities, choice of self-financing form and model of economic management [11].

However, the economic model of the territory of self-government will not be completed without identifying the sources of funding for socio-cultural activities, administrative and legal services to residents, local government retention and activities financed from local budgets, with the deduction of investment in innovative development.

\section{Research Results}

The quintessence of self-government and selffinancing is to identify systemic features of economic autonomy and to build a financial and economic mechanism for managing territorial processes [12].

The main provisions of economic autonomy of the administrative-territorial formation are set out below.

Targeting economic autonomy is, above all, a reasonable boundary in harnessing the region's economic opportunities aimed at developing and operating a socio-economic environment.

Important signs of economic independence of the region are:

1. Establishing relations between the united territorial community and the state on the basis of recognition of autonomous economic interests; independence of decision-making in the rational use of nature, development of industrial, social infrastructure and establishment of dependence of economic capacities of local authorities on the efficiency of functioning of economic entities located in the community;

2. Clear delineation of organizational, social, economic and legal relations between the subordinate communities and resolving the questions about which of them and for which specific economic entities of the common territory are able to provide the best socioeconomic, organizational and economic conditions for effective work, and their actions would be in line with territorial interests and mutually beneficial;

3. Formation of investment and production policy on the basis of innovation-oriented economic development of the territories, a clear definition of priorities of socio-economic development and the division of needs in time and space. The organization and management of the process of investing in the development of local infrastructure is carried out in a systematic approach to investment projects. The economic performance of the region's economy is guaranteed by the implementation of the economic and social development program;

4. Systematic nature of all elements and structural levels of economic governance and management of the region is ensured by the development and implementation of regional integrated programs that will link into a closed system of consumption and production, giving these relations a visible economic connection. The legal justification of these relations will ensure the optimality of structural elements within the territorial community, which form an integrated economic complex with the inclusion of a 
mechanism of financial state support for territorial communities at the stage of implementation of the integrated program;

5. Formation of the internal market for goods with the introduction of a system of commercial agreements between enterprises and selfgovernment bodies based on the objectives of long-term regional policy. Each territorial unit develops and implements a long-term strategy for structural changes in the economy based on the mutual interest of all entities located in the community as a result of the activity;

6. Justification of the list of forms of effective use of monetary savings of residents of territorial communities, which can be directed as investments in the development of economies of the region, and the community becomes a subject of self-financing relations;

7. Expansion of a set of financial instruments for efficient use of regional resources, their continuous reproduction in accordance with the needs of enterprises, organizations in the current and future periods. This approach will change the nature of the relationship between selfgovernment bodies and economic entities: the requirements for the introduction of the latest technologies, the rational use of water, forest, land resources, the balance of the needs of enterprises in the preparation of human resources will increase;

8. Reconciliation of current and perspective problems with regard to development of community territories with economic entities by working out joint actions with the selfgovernment bodies, which allow directing local resources to create necessary resources and infrastructural units for the future;

9. Formation of a strategy with reference to export of the region in the field of production comprising products from local resources. The Export Development Program should focus on supporting producers of goods and services engaged in foreign economic activity, promoting goods and services produced and supplied by the region to the world market in close interaction of local government with the relevant state structures.

The main provisions of the model of economic independence of the region outline the effective implementation of the mechanism of decentralized management of the process of regional development, combination with integration processes in the economy of Ukraine, which will significantly increase the self-sufficiency of the administrative level.
In our opinion, a constructive approach in the creation of a local community economy is the economic factors and the mechanism of their realization. Such an economic model is based on the concept of economic equality of all subjects and parties of property where the region and center of functioning are absolutely equal.

In practice, territorial communities are not empowered to influence economic levers, as this is within the competence of the state. That is why in the construction of the model of economic mechanism of the territorial community the main task is to optimize the proportions between own and delegated powers, own and appropriated revenues, and economic levers of self-management by economic entities are transformed into the existing system of economic regulators of territorial processes. Financial and economic regulators are specific about the conditions of economic activity of a certain territorial community and perform the functions of economic coercion, influence and stimulation in compliance with the rules of economic relations.

Territorial diversification will ensure effective management of:

1. Streamlining of financial relations on the use of natural resources in terms of self-government. The remuneration of enterprises located in the community for natural resources is primarily focused on reimbursement of the costs of their reproduction as well as the rental income generated by the use of high quality natural resources. The main difficulties are the lack of tools for the assessment of natural resources, and especially those for the rational use, which could be influenced by the financial authorities. Therefore, in the process of further improvement of the economic mechanism, it is necessary to expand the rights of territories in fiscal policy, to estimate the value of resources, which will provide opportunities for their value distribution between the state as the owner, the communities as owners and the organizations empowered to operate in the economic process;

2. Managing the processes of innovative investment development of the region's economy, concentration of production and activities. The territorial community should focus its activities on the creation of a qualitatively new territorial structure of production and public services in order to attract investment and innovate.

A benchmark for regional industrial policy making on a decentralized basis may be a national regional development strategy for 2020. Economic regulators must be resource-based - pay for resources, perform economic coercion to effectively use economic resources, preferential taxation, or release taxes of certain industries and activities of the territory as the main lever of influence on the formation of rational, from an economic point of view, territorially concentration; 
3. A comprehensive approach to the development of territorial structures as highly efficient national innovation ecosystems. Practically developed decentralized industrial policy should be implemented in a targeted program focused on the activities of the territorial community with the identification of the main organizational and economic components of a certain form of ecosystem, which attract specialists "generators of technological ideas", and they in turn attract financial capital, related and service enterprises stimulate further concentration of competencies.

In modern conditions of regional development, the problem of determining strategic priorities and directions of development of regions with orientation of activity of territorial communities comes first.

Since agriculture is a priority for the vast majority of territorial communities, this vector should be an impetus for the introduction of a territorial-industrial approach to agricultural development, raw material processing, food production and production and commercial activity.

The main tool for ensuring the economic growth of rural territorial communities, as a basic link of state-building, is the creation and development of national innovation ecosystems, in particular cluster programs capable of attracting investment, promoting high-tech development.

According to the Program for the Development of Scientific, Technical and Innovative Activity of the Ivano-Frankivsk Region until 2020, we have created a cluster program "Production of baby food based on organic cow's milk" for the administrative-territorial area of Rohatyn, Bukachivtsi United by the Carpathian Scientific and Analytical Center territorial community.

The main motive of the program is responsibility and obligation to the society for the rational use of ecologically clean lands, promoting the development of organic farming and stimulating the development of territorial communities. The creation of a local project is dictated by the unbalanced diet of Ukrainian children, which significantly affects their health, since milk and dairy products are the major component of the daily diet among children, which contain all the necessary substances for the growth and development of the child.

Today, consumers are increasingly beginning to trust the Ukrainian manufacturer for high quality products and low prices. When choosing baby food, moms focus on food composition, enrichment with vitamins and minerals, lack of genetically modified ingredients, and baby's tastes.

The basis of the cluster program of the territorial community is a projected model of ecological animal husbandry and agriculture, a raw material base is investigated, the material and technical base in the motivated zone is evaluated, the range of baby dairy products is selected and the latest technologies of their production are selected, the organizational structure is created, and the organizational structure is created (Fig. 1).

The cluster model of management of the process of production of infant dairy food unites dairy producers - farms, milk processing enterprises in a given range, trade network, universities, standardization bodies, research centers, associations responsible for training, responsible for information, technical support from the practical point of balancing the mutual interests, by which the cluster participants provides the mechanism of internal financial-credit relations (Fig. 1).

The financial and credit mechanism provides free movement of financial resources within the cluster, there is a transfer price mechanism, preferential lending to the production of baby milk, preferential taxation of the profits of participating banks from directing funds to the agricultural sector. Pricing is driven by pricing under the influence of supply and demand for products, and the entities in the technology chain are focused on the final market price. The profit received is distributed in proportion to the costs incurred by the participants: agriculture processing - trade.

This approach to the formation of financial relations in the middle of the cluster stimulates the reduction of own costs of production, the introduction and approximation of these costs to the level of enterprises in developed countries.

The vertically integrated model of baby milk production is determined by radical changes in the agricultural sector with the expansion of agroecological production, the realization of the interests of the united territorial community in the creation of new high-tech jobs attractive to skilled specialists and workers, high levels of rural employment. According to the feasibility study, more than 350 modern jobs will be created in the rural territories of the united territorial community, and the cost of the program will be at least UAH 280 million [13].

The implementation of the created cluster program of the region will allow forming the basis of the system respecting regulation of the food, consumer market not only to meet human needs but in terms of ensuring the economic, social and political stability of society.

After all, the market for functional products in Ukraine is not developed. In the world market, the level of concentration of dairy production of baby food in several leaders (Nestle, Bristol-Myezs, Abbott, Laborarories, Novartis, Numieo, Heinr, Wyeth, and Danone) is increasing. At the state level, a market for baby food products should be created as a prerequisite for creating a favorable external and internal environment for the development of food complex enterprises.

Today it is quite obvious that structural restructuring of the economy for the purpose of rapid and comprehensive economic recovery of the country is impossible only at the expense of internal resources.

Government policy should be aimed at mobilizing available resources, attracting investment and credit 
in export-oriented industries. On the other hand, the policy of the state should stimulate the activity of enterprises and private investors in creating integration structures for concentration of capital. In these circumstances, the state itself should be the main investor guarantor of the private investor at the initial stage of investing in the amount of 20-30 percent of the cost of the projects.
For a developing business, it is necessary to address the issue of innovative preferential lending, external purpose loans, the identification of several authorized state banks, or the creation of territorial investment banks that will provide medium-sized lending on preferential terms. Today, Ukrainian and international banks should be identified as important and priority actors in reforming Ukraine's economy.
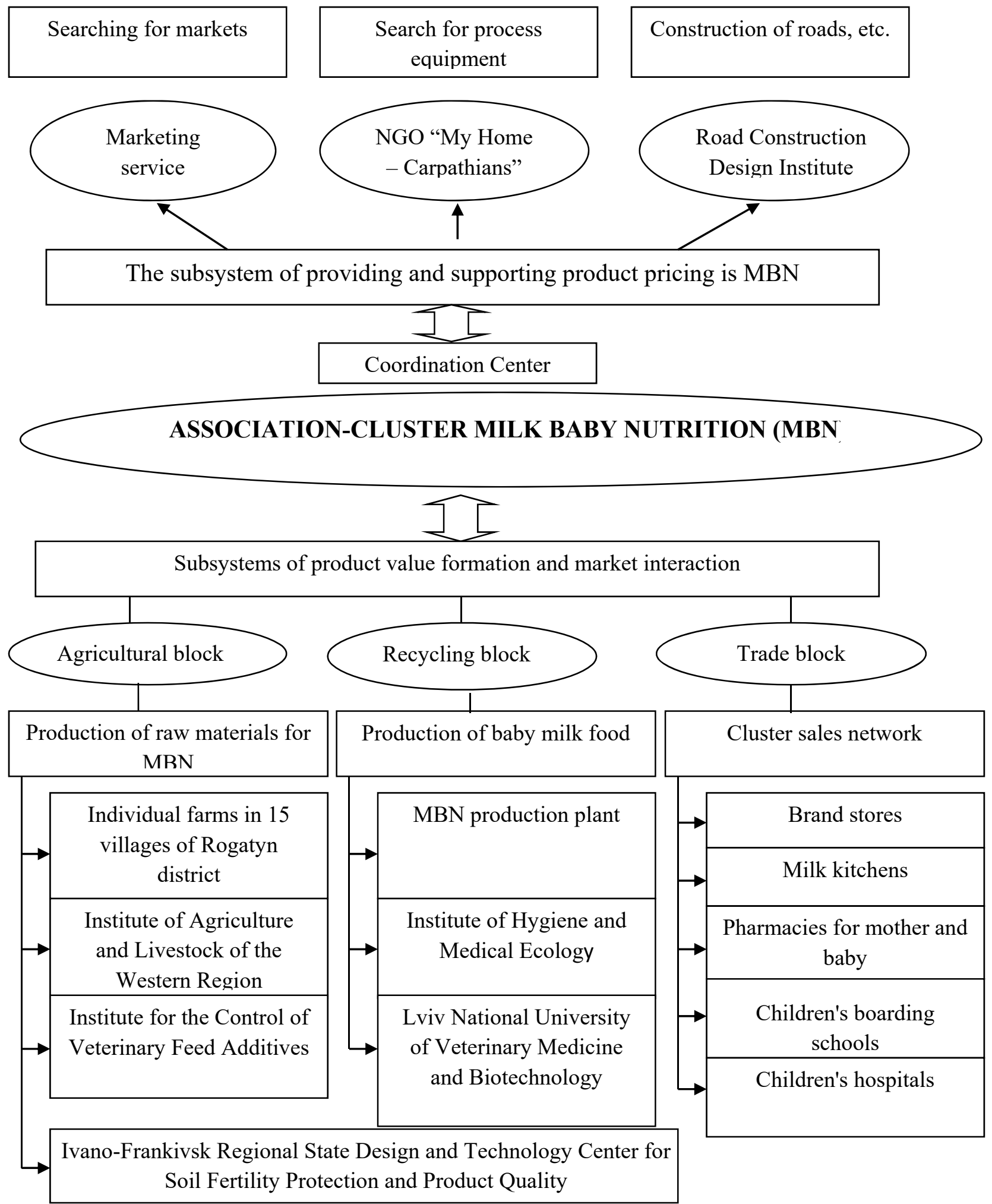

Figure 1. Cluster model of organization of management of the process of production of baby milk nutrition [developed by the authors] 
However, production clusters and the basis of integration of state and business resources oriented towards the end result in a single technological chain "research, concept - design - production - trade" will be able to organize the interaction of banks and enterprises in a certain preferential mode.

Time requires the legal status of clusters as a stateof-the-art system for managing business entities.

4. Compliance with costs and outcomes in decentralized settings. The observance of the dimension between the costs and the results of the functioning of the territorial economy should be considered from the point of the reproduction process. Integrated economic and social development of the territory is ensured only through the management of the regional reproduction process, which is associated with the large-scale use of national income to accumulate, consume, and create a clean product as a result of the functioning of the system.

This comparison provides relevant information about what produces or consumes a region's national income.

It should be noted that the expenditures of the region are determined by that part of the national income that is used for raising the living standards of the inhabitants, for the reproduction of regional resources and environmental protection, for the creation of social infrastructure and development of the overall regional infrastructure base. Naturally, to solve these problems, each self-financing enterprise provides certain resources that can be used or transferred to local governments for the comprehensive development of the Territorial system. According to the Law of Ukraine "On measures of state regional policy", self-government bodies are horizontal and as the horizontal ties develop in the region such conditions are created under which they accumulate resources for public consumption and not production accumulation.

The economic function of the mechanism regarding complex development of the regional system is financial relations, which determine the formation of equivalent relations between the associated enterprises and organizations on the one hand and management centers on the other. Under such a system of economic relations, the region and the center fall into absolutely equal initial conditions, which stimulate both subjects of property relations. Due to its considerable economic and economic potential, the Center concentrates its funds on strategically important national directions of social, structural innovation policy. The regions still have sufficient resources to quickly address the ongoing problems associated with improving the living standards of the region's residents.
In this context, in order to evaluate the effectiveness of the functioning of the economic system of the region, the territorial community, it is important to create a single method of calculating the aggregate purity of the product for all regions, to experiment in a number of regions with different economic development to regulate the relations of ownership of territorial communities legally, to balance economic and social protection of the population of rational environmental management [14].

Establishment and application of a defined theoretical model of financing in practice creates a scientifically sound basis for streamlining financial flows between structural units, improving the effectiveness of management decisions and using innovative approaches to internal planning and budgeting processes [15].

First of all, we are talking about creating a new model that can operate on the basis of scientifically sound principles of economic cooperation. The perfection of the model depends on the depth of the study of factors influencing its formation [16].

\section{Conclusion}

Consistent implementation of the economic mechanism opens the possibility for the transition to economic management methods as a necessary attribute of economic freedom. This will facilitate the optimal synthesis of centralized management with economic autonomy, establishing an equivalent exchange between the enterprise and the region.

The basis of economic relations between the region and state bodies, with other regions should be self-sustaining - the excess of the region's revenues over expenditures. This creates the conditions for the construction of optimal distribution relations, which are essential in the conditions of economic independence, both to enterprises and to the territorial community and the region as a whole.

The concept of economic equality of all entities and parties of ownership should become the dominant model of the economic mechanism. It is this system of economic relations between the center and the region that aligns the initial conditions, which sufficiently stimulates both subjects of property relations. 


\section{References}

[1]. Voronkova, O. Y., Akhmetshin, E. M., Sycheva, I. N., Shpakova, R. N., Pashkova, E. Y., \& Poltarykhin, A. L. (2018). Economic Mechanism of Regulating Land Relations in the Agricultural Sector of Russia. European Research Studies Journal, 21(4), 280-291.

[2]. Laiko, O., \& Kwiliński, A. (2017). Tools for the improving of investment climate in territorial communities: challenges and perspectives for Ukrainian economy. Economics. Ecology. Socium, 1(1), 93-103.

[3]. Sandal, J. U., Yakobchuk, V., Lytvynchuk, I., \& Plotnikova, M. (2019). Institutions for Forming Social Capital In Territorial Communities. Management Theory and Studies for Rural Business and Infrastructure Development, 41(1), 67-76.

[4]. Tkachuk, I. H. (1994). Economic independence of the region: monograph. Scientific Opinion.

[5]. Mykytenko, V. V., \& Demianiuk, O. O. (2009). Technologies for managing the economic security of production and economic systems. Ukraine's Development Strategy: Economics, Sociology, Law, (3-4), 101.

[6]. Melnychuk, Y. M., Vinnytska, O. A., \& LA, C. (2019). Management of financial results of insurance companies as an activator of the innovationinvestment process. Economies' Horizons,(3)10, 4-10.

[7]. Butko, N. P. (2017). Bifurkatsionnoe sostoianie iadra gosudarstvennogo sozidaniia Ukrainy $\mathrm{v}$ usloviiakh realizatsii evrointegratsionnogo kursa [The bifurcation state of the state building of Ukraine in the conditions of implementation of the core of the European integration course]. Ekonomika Ukrainy-Economy of Ukraine, 10(663), 49-64.

[8]. Belenkyi, P.Yu. (2003). Regional policy and market infrastructure. Socio-economic studies in transition. Regional policy: experience of the European Union and its adaptation to the conditions of Ukraine, 5, 80125.
[9]. Khvesyk, M. A., Bystriakov, I. K., \& DV, K. Financial and economic mechanism for capitalization of natural resources of the united territorial community. Finance of Ukraine, (4), 19-40.

[10]. Melnychuk, Y., \& Slatvinskyi, M. (2019, October). Economic Security Governance and Financial Independence of Telecommunication Companies. In 2019 IEEE International Scientific-Practical Conference Problems of Infocommunications, Science and Technology (PIC S\&T) (pp. 133-138). IEEE.

[11]. Melnychuk, Y. M., Shkolenko, O. B., Gumeniuk, A. V., \& Melnik, V. V. (2018). Bank deposit as a direction of investment activity's activation of insurers in life insurance. Financial and credit activity: problems of theory and practice, 4(27), 4148.

[12]. Tkachuk, I. H., Kropelnytska, S. O., \& AD, P. (2009). The Constellation Folk Arts Cluster: Mathematics. Commentary, Tips.

[13]. Kucheruk, T. H. (2011). Mekhanizm innovatsiinooriientovanoho ekonomichnoho rozvytku rehioniv $\mathrm{z}$ problemy ratsionalnosti funk-tsionuvannia. The mechanism innovation-oriented economic de.

[14]. Kropelnytska, S.O., Myhovych, T. \& KyleshaLiubinets, M. (2019). Development and realization of social projects in ukraine. Ekonomika ta pidpryyemnytstvo,, 1 (106).

[15]. Kot'kalova-Lytvyn, I. V. (2013). Teoretychna model' upravlinnya finansovymy potokamy korporatsiyi. Efektyvna ekonomika, (11).

[16]. Tryguba, A., Ratushny, R., Shcherbachenko, O. \& Bashynsky, O. (2018). System Approach to Investigation of Projects of Fire-Fighting Systems' Functioning and Development of United Territorial Communities. TEKA. An International Quarterly Journal on Motorization, Vehicle Operation, Energy Efficiency and Mechanical Engineering. LublinRzeszow, 18(1), 5-12. 